\title{
Groundwater flow fans fears over UK nuclear waste store
}

London. New doubts have arisen over the safety of locating the United Kingdom's deep underground repository for radioactive waste at the proposed site at Sellafield, in Cumbria. The Radioactive Waste Management Advisory Committee (RWMAC), which advises the government, fears that contaminated water from the proposed repository site could rise to the surface, polluting surrounding land and water.

In a report published last week, $\mathrm{RWMAC}$ claims that its review of hydrogeological data from the area shows there is "inconsistency" between observed groundwater behaviour and results from computer-based modelling, which predict that water from the site would flow out into the Irish Sea.

The computer modelling has been carried out by UK Nirex Ltd, the nuclear industry's waste disposal company charged with selecting and constructing a repository site. The company has so far drilled more than 10 deep boreholes in West Cumbria for data collection using techniques that RWMAC acknowledges to be at the "leading edge" of international experience.

But in its annual report, RWMAC highlights what it sees as inadequacies in Nirex's conceptual modelling, focusing on the waste company's prediction of groundwater flow around the site.

According to RWMAC, data from the latest Nirex report (Report No. 525) indicate an upward movement of groundwater from the proposed repository site, which is located within the Borrowdale Volcanic Group, as it moves west through the Sherwood Sandstone Group (SSG) towards the sea. Groundwater is discharged to the surface from the SSG near the coastal margin (see diagram).

But the pathline predicted by one of Nirex's fracture flow computer models, NAMMU (shown in black on the diagram) predicts that water from the repository site will make a sharp decline along a fault line,

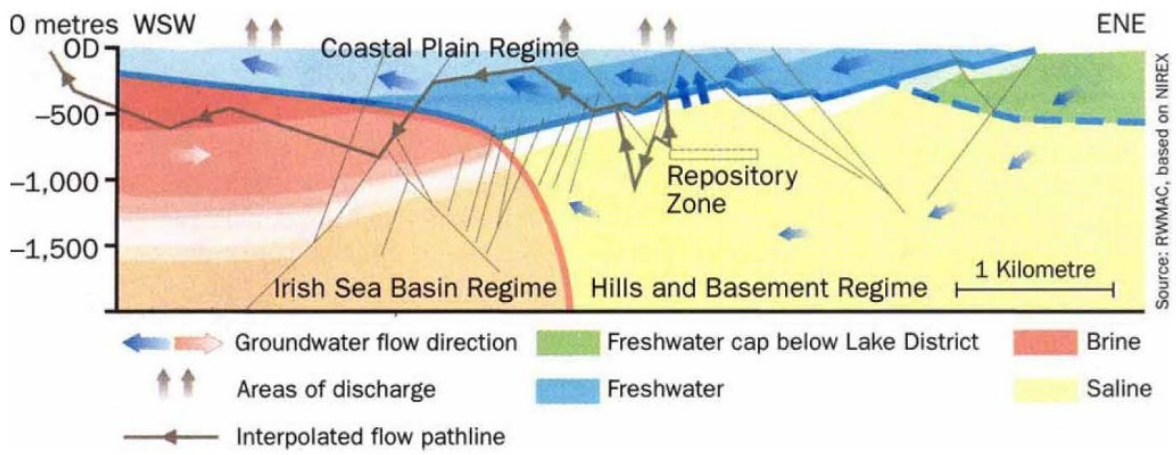

RWMAC's analysis suggests that Nirex's predictions of how water will move may not be born out in practice.

against the upward flow of the groundwater. Given that this would mean lower density fresh water moving downwards into a higher density brine, the interpolated pathline becomes "difficult to conceive", concludes RWMAC.

"As a result, the discharge of groundwater from the repository zone to the land surface above the repository site is no less plausible than the flow models illustrated by Nirex," says the report. It calls on Nirex to reconcile the differences between observations and computer-modelling predictions through model validation and data verification.

"We will ultimately see a repository built in Britain. Whether it is at Sellafield is a different matter. Clearly there are major questions that need answers," said Sir John Knill, chairman of RWMAC, at the launch of the report.

Tom Curtin, a spokesman for Nirex, points out that the company has still to collect all the information it needs, and expects to take at least three or four more years to do so. "If we had all the information right now we'd apply for planning permission for the repository itself," said Curtin. Instead, Nirex intends to seek planning permission in the next few weeks for the construction of a rock characterization facility (RCF) near the repository site for further investigation into groundwater flow. The RCF, costing around $£ 120$ million in addition to the $£ 300$ million that Nirex has already spent studying the site, is seen as "vital" to the process.

If all goes according to plan, work on the RCF will begin in 1995 . Settling the question of a long-term waste site represents "a key policy question", according to another report published last week by the Parliamentary Office of Science and Technology (POST) on the government's long-awaited review of the prospects for the nuclear industry, announced last month.

Maggie Verrall

\section{Fossil inquiry finds Indian geologist guilty of plagiarism}

New Delhi. An inquiry by Panjab University in Chandigarh has apparently found the prominent Indian geologist Viswa Jit Gupta guilty of plagiarism, of recycling fossils and of claiming to have made discoveries in localities he had not visited.

The inquiry, prompted by concerns over Gupta's research that were first raised by the Australian geologist John Talent (see $\mathrm{Na}$ ture 338, 613; 1989), also claims that Gupta was guilty of misleading his co-authors. The university is now deliberating on what action to take against Gupta, who still retains his position as professor at the university.

The report of the inquiry officer, M. S. Gujral, has been submitted to the university's vice-chancellor, T. N. Kapoor, and has been circulated among members of the 'syndicate', the university's governing body.

In particular, Gupta had been charged with claiming that fossils collected from museums and other sources were his own samples recovered on field trips, and that the many scientific publications based on these fossils had distorted the literature on Himalayan geology.

Two earlier investigations - one by the Geological Survey of India and another by the Society for Scientific Values (SSV) had independently found Gupta guilty. But it was only after the cancellation of funds from the University Grants Commission and adverse publicity in the international scientific press (see Nature 355,$660 ; 1992$ ) that Kapoor decided to act.

The inquiry covered not only Gupta but also his four co-authors, all of whom had sided with Talent. Although the report is said to confirm Talent's charges against Gupta, it exonerates his co-authors of being party to the fraud.

Despite the delay - the inquiry started in February 1992 - the final verdict has been generally welcomed by the scientific community. "I am very, very happy it is over," said A. S. Paintal, who carried out his own investigation of the charges against Gupta as president of SSV in 1991.

Gupta defended himself against the charges, but apparently failed to produce any evidence sufficient to refute the charges. $\mathrm{He}$ was unable to remember the dates of his expeditions, bluntly told the inquiry that he did not keep field notes, and retracted a document submitted earlier to Gujral detailing a field trip to Khemkul La.

India's geologists are keenly awaiting the syndicate's decision on Gupta's punishment. Some are demanding firm action. "We cannot let Gupta off mildly," says Paintal. "He must go." Gupta himself has not been available to comment on the inquiry's conclusions.

K. S. Jayaraman 